\title{
PENGARUH ALAT PERMAINAN EDUKATIF TERHADAP ASPEK PERKEMBANGAN PADA ANAK PRA SEKOLAH DI WILAYAH PUSKESMAS ONDONG KABUPATEN KEPULAUAN SIAU TAGULANDANG BIARO
}

\author{
${ }^{1}$ Sry Nur Hasana Sain \\ ${ }^{2}$ Amatus Yudi Ismanto \\ ${ }^{3}$ Abram Babakal
}

\author{
${ }^{1}$ Kandidat Skripsi Program Studi Ilmu Keperawatan Fakultas Kedokteran \\ Universitas Sam Ratulangi Manado \\ ${ }^{2}$ Bagian Pediatri Program Studi Ilmu Keperawatan Fakultas Kedokteran \\ Universitas Sam Ratulangi Manado \\ ${ }^{3}$ Bagian Pediatri BLU RSUP Prof.Kandou Manado \\ Email: srysain@gmail.com
}

\begin{abstract}
Abstrak Alat Permainan Edukatif adalah jenis permainan yang mengandung nilai pendidikan yang berfungsi untuk merangsang daya imajinasi anak dalam proses perkembangan kongnitif, proses kegiatannya yaitu pemberian stimulasi sehingga dapat meningkatkan aspek perkembangan dalam proses tumbuh kembang anak yang dinilai dari perkembangan motorik kasar, motorik halus, kemampuan bicara dan bahasa serta kemampuan sosisalisasi dan kemandirian. Tujuan penelitian adalah mengetahui pengaruh alat permainan edukatif terhadap aspek perkembangan anak pra sekolah. Metode penelitian one group pre-post test dimana peneliti mengobservasi sebelum dan sesudah perlakuan. Sampel yang digunakan purposive sampeling, besar sampel 17 responden. Data yang diperoleh dianalisa dengan uji wilcoxon signed ranks test. Hasil penelitian menunjukkan $(\mathrm{p}=0,000<\alpha=0,05)$ artinya ada pengaruh alat permainan edukatif terhadap aspek perkembangan anak pra sekolah. Dari hasil penelitian ini disarankan kepada orang tua dan pemimbing lebih memperhatikan masa perkembangan anak pra sekolah khususnya kemampuan berbicara dan berbahasa serta sosialisasi dan kemandirian.
\end{abstract}

Kata kunci: Anak pra sekolah, Aspek perkembangan, Permainan edukatif.

\begin{abstract}
Educated gane tool is a kind of gane which consists of educational value it is functioned to stimuli children's imagination cognitively. The process is to give stimulus so it can increase the development skill and socializing a independency. The purpose of this research is to know the effect of educated game tool to preschool children development. The method of this research is one pre-post test group which the researcher observed before and after treatment. The sample is purposive sampling, total of the sampling is 17 respondent. Data which was gotten then analyzed by using wilcoxon signed ranks. The result of the research shows $(\mathrm{p}=0,000<\alpha=0,05)$, it means that there is effect from educated game tool to pre school childreen. From these result, it is suggested to parents a school to pay more attention to pre school children's development especially speaking, language, socializing a independence ability.
\end{abstract}

Keyword : Pre school children, aspect of development, educated games. 
Anak pra sekolah adalah anak yang berumur 36-60 bulan, pada masa ini anak dipersiapkan untuk sekolah, dimana panca indra dan sistim reseptor penerima rangsangan serta proses memori harus sudah siap sehingga anak mampu belajar dengan baik, proses belajar pada masa ini adalah dengan cara bermain (DepKes RI, 2006). ${ }^{1}$ Dari hasil kajian neurologi, pertumbuhan sel jaringan otak pada anak usia 0-5 tahun mencapai 50\%, oleh karena itu, anak-anak pada rentang usia ini wajib mendapat perhatian khusus keluarga dalam pertumbuhan dan perkembangan guna mengoptimalkan kecerdasan anak (Patmonodewo, 2003). ${ }^{2}$

\section{METODOLOGI PENELITIAN}

Jenis penelitian Pra-Experimen desain one group pretest- posttest yakni suatu rancangan penelitian dimana peneliti sudah melakukan observasi pertama (pretest) sehingga peneliti dapat menguji/mengevaluasi yang kedua (posttest) untuk perubahan yang terjadi setelah adanya perlakuan (Riyanto, 2011) ${ }^{3}$.

Populasi adalah anak pra sekolah yang bersekolah di Taman Kanak-kanak di wilayah Puskesmas Ondong. Teknik pengambilan sampel secara tidak acak (non random) yaitu pengambilan sampel berdasarkan kriteria tertentu (purposive sampeling) yang sebelumnya ditetapkan oleh peneliti, subjek yang memenuhi kriteria tersebut (kriteria inklusi) menjadi anggota sampel (Sanjtaka, 2012) ${ }^{4}$ Kriteria inklusi: Anak usia pra sekolah umur 3-5 tahun' anak dengan persetujuan orang tua/pengasuh bersedia untuk diteliti, anak sehat, tidak sakit dan anak setelah pre test dengan KPSP penilaian meragukan.

Alat ukur menggunakan Kuesioner Pra Skrinig Perkembangan (KPSP), kriteria penilaian pada aspek perkembangan terdiri dari: motorik kasar, motorik halus, kemampuan berbicara dan berbahasa serta kemampuan bersosialisasi dan kemandirian.
Penelitian dilakukan pada bulan januari, tahun 2013, tempat penelitian dilaksanakan di Taman Kanak-Kanak GMIST Immanuel Ondong Kabupaten Kepulauan Sitaro.

\section{HASIL PENELITIAN}

Analisa univariat digunakan melihat distribusi gambaran umum atau frekuensi mengenai variabel penelitian yang berkaitan dengan responden. Bertujuan mengetahui pengaruh pemberian alat permainan edukatif terhadap aspek perkembangan anak pra sekolah dengan jumlah sampel 17 orang yang diobservasi sebelum diberikan perlakuan dan sesudah diberikan perlakuan, dilaksanakan tanggal 8 Januari 2013 s/d 21 Januari 2013. Responden terbanyak umur 5 tahun 15 siswa, responden terbanyak jenis kelamin laki-laki 9 siswa, responden terbanyak berat badan 12-16 kg 10 siswa dan terkurang berat badan 22-26 kg 2 siswa, responden terbanyak tinggi badan 102-106 cm 10 siswa dan responden terkurang pada tinggi badan 97-101 cm 2 siswa. Responden terbanyak aspek perkembangan sebelum perlakuan didapatkan kriteria meragukan 17 siswa dan responden terbanyak aspek perkembangan setelah perlakuan didapatkan kriteria normal berjumlah 14 siswa. Pada analisa bevariat, hasil uji wilcoxon signed ranks test didapatkan nilai rata-rata perkembangan sebelum diberikan perlakuan 2.0000 dan sesudah diberikan perlakuan 1.1765 dapat disimpulkan setelah diberikan permainan edukatif, tingkat perkembangan dengan penilaian KPSP dari responden kriteria meragukan berkurang meningkat menjadi kriteria normal.

\section{PEMBAHASAN}

Karakteristik Responden: awal masa kanak-kanak berlangsung dari usia 2-6 tahun, oleh orang tua disebut usia problematis, menyulitkan, atau menurut ahli psikologi sebagai prakelompok, penjelajah atau usia bertanya, 
sedangkan oleh para pendidik disebut usia/ anak pra sekolah (Rahman, 2009). ${ }^{5}$ Pengaruh alat permainan edukatif terhadap aspek perkembangan sebelum dan sesudah perlakuan: Alat permainan edukatif adalah alat permainan yang dapat mengoptimalkan perkembangan anak yang disesuaikan dengan usia dan tingkat perkembangan anak (Permana, 2007) ${ }^{6}$

Pengembangan aspek fisik melalui kegiatan yang dapat merangsang pertumbuhan fisik anak (motorik kasar dan motorik halus), aspek bahasa melatih berbicara dengan menggunakan kalimat yang benar, aspek sosial dilakukan dengan cara berhubungan/berinteraksi dengan orang tua, keluarga, saudara dan masyarakat. Perkembangan menandai maturitas dari organ-organ dan sistem-sistem, perolehan ketrampilan, kemampuan yang lebih siap untuk beradaptasi terhadap stres dan kemampuan untuk memikul tanggung jawab maksimal dan memperoleh kebebasan dalam mengekspresikan kreativitas anak (Nursalam, 2005). ${ }^{7}$

Penilaian Tumbuh Kembang anak dideteksi dengan menggunakan Kuesioner Pra Skrining Perkembangan (KPSP) yang disesuaikan dengan usia anak. Apabila dideteksi perkembangan anak hasilnya sesuai dengan usia perkembangan berarti anak berhasil menyesuaikan diri dengan tahap perkembangan secara normal, dan jika dideteksi diperoleh keterlambatan (meragukan) dan penyimpangan pada perkembangan anak, maka diberikan intervensi stimulasi alat permainan edukatif selama 2 minggu per 3-4 jam setiap hari (DepKes RI, 2006)

Hasil penelitian dari 17 responden didapatkan pada tahap pre test yaitu kriteria meragukan berjumlah 17 responden. Peneliti melaksanakan penelitian bersama satu guru pembimbing TK GMIST IMMANUEL Ondong selama dua minggu dengan pemberian perlakuan/intervensi stimulasi alat permainan edukatif kepada anak pra sekolah berlangsung selama 3-4 jam sehari dari pukul 07.30-10.30 wita. Stimulasi alat permainan edukatif yang diberikan untuk aspek perkembangan kemampuan berbicara dan berbahasa adalah permainan peran (dramatic role play) dimana peneliti mengajak berkomunikasi dengan responden yang dihubungkan dengan pertanyaan untuk penilaian KPSP, sehingga anak mendengar, bisa mengerti dan bisa berbicara dengan menggunakan bahasanya untuk menjawab secara spontan setiap pertanyaan yang diajukan kepada anak hal ini dapat mengembangkan potensi untuk kemampuan verbal anak. Stimulasi alat permainan edukatif untuk aspek perkembangan kemampuan bersosialisasi dan kemandirian diberikan permainan bersama (associative play) yaitu bagaimana cara anak berinteraksi sesama teman disekolah dengan latihan melepaskan dan memakai sepatu sendiri setelah dilakukan pengukuran tinggi badan dan penimbangan berat badan sehingga dapat mengembangkan potensi anak untuk kemampuan berkawan dan berpikir anak. Stimulasi alat permainan edukatif untuk aspek perkembangan motorik kasar, diberikan permainan bersama (Cooperative play) adalah cara melempar dan menangkap bola bertempat pada halaman sekolah, dibentuk dua lingkaran masing-masing lingkaran anak perempuan dan lingkaran anak laki-laki, pemberian stimulasi alat permainan ini dapat mengembangkan potensi anak untuk kemampuan mencintai keindahan alam dan kemampuan kinestetik. Pada permainan ketrampilan (skill play), peneliti memberikan alat permainan edukatif yang distimulasikan dengan pemberian kertas bergambar garis lurus, garis lingkaran, garis silang dan kertas bergambar hitam putih sehingga merangsang imajinasi anak untuk bisa mengikuti bentuk garis dan mening-katkan daya kreativitas anak untuk bisa mewarnai gambar tersebut dengan pensil berwarna (krayon) hal ini dapat mengembangkan aspek perkembangan motorik halus, mengembangkan potensi anak untuk kemam-puan logika dan visual anak serta perkembangan kongnitif pada fase 
praoperasional dimana anak mengenal bentuk dan warna.

Adapun kepada orang tua/pengasuh anak, peneliti memberikan edukasi berupa penyuluhan agar selalu memberikan kebutuhan dasar tumbuh kembang pada anak dirumah dan lingkungan berupa kebutuhan dasar asuh (pemberian kebutuhan nutrisi yang mencukupi dan seimbang kepada anak), kebutuhan dasar asih (memberikan dukungan/dorongan agar anak menjadi pribadi yang mandiri) dan kebutuhan dasar asah (pemberian stimulasi terarah/rangsangan positif berupa bermain dengan kata-kata seperti bercerita dan berdiskusi sehingga perkembangan tumbuh kembang anak pra sekolah berkembang secara optimal. Hasil penelitian post test dengan penilaian KPSP didapatkan kriteria normal 14 responden, kriteria meragukan 3 responden dan tidak ditemukan kriteria penyimpangan. Pemberian perlakuan/intervensi alat permainan edukatif diberikan kepada 17 siswa dengan kriteria meragukan.

Responden yang diberikan alat permainan edukatif tampak senang dengan jenis permainan yang diberikan, sebagian besar menunjukkan sikap yang sangat kooperatif pada saat penelitian. Setelah data terkumpul peneliti menganalisis data menggunakan uji wilcoxon signed ranks test dengan nilai $\mathrm{p}$ (0.000) lebih kecil dari $\alpha$ (0.05) dapat disimpulkan bahwa ada pengaruh alat permainan edukatif terhadap aspek perkembangan sebelum dan sesudah pemberian stimulasi pada anak pra sekolah di TK GMIST Immanuel Ondong bulan januari tahun 2013. Hasil ini didukung oleh penelitian sebelumnya oleh dr. Permana SpAn, tahun 2007 dengan penilaian menggunakan cronbach test berkesimpulan bahwa ada perbedaan perkembangan anak pada kelompok anak pra sekolah yang mendapat stimulasi dan kelompok anak pra sekolah yang tidak mendapat stimulasi dengan Alat Permainan Edukatif. Hasil penelitian ini membuktikan teori keperawatan menurut
Soetjingsih, (1995) ${ }^{8}$ bahwa alat permainan edukatif adalah alat permainan yang mengandung nilai pendidikan sesuai usia dan tingkat perkembangan anak yang berfungsi untuk merangsang perkembangan fisik, bahasa, kongnitif dan sosial anak sehingga dapat mengoptimalkan perkembangan anak.

\section{SIMPULAN}

Aspek perkembangan pada anak sebelum diberikan alat permainan edukatif didapatkan kriteria meragukan sangatlah banyak.

Aspek perkembangan pada anak sesudah diberikan alat permainan edukatif mengalami peningkatan perkembangan dari kriteria meragukan menjadi kriteria normal yang menunjukkan bahwa hasil tersebut sudah baik.

Ada pengaruh alat permainan edukatif terhadap aspek perkembangan anak pra sekolah sebelum dan sesudah pemberian stimulasi.

\section{SARAN}

Sebaiknya lebih banyak stimulasi alat permainan edukatif yang diberikan kepada anak sehingga merangsang daya imajiansi anak untuk berfikir dan berkreativitas mengembangkan potensi diri anak dalam meningkatkan perkembangan motorik kasar, motorik halus, kemampuan bicara dan bahasa serta kemampuan sosialisasi dan kemandirian.

Orang tua dan pengasuh anak sebaiknya stimulasi alat permaianan edukatif selalu diberikan dalam setiap aktivitas dan berikan dorongan serta dukungan positif dari lingkungan kepada anak karena anak yang sering dan banyak mendapatkan stimulasi yang terarah akan cepat berkembang dibandingkan anak yang kurang mendapatkan stimulasi.

Ditujukkan bagi pengembangan pendidikan keperawatan disarankan kepada institusi keperawatan untuk sub bagian pediatrik sebaiknya diberikan latihan dasar stimulasi alat permainan edukatif kepada mahasiswa, sehingga bisa menjalankan tindakan independen perawat sebagai pendidik khusus 
meningkatkan perkembangan kongnitif pada anak.

\section{UCAPAN TERIMA KASIH}

Penulis menyampaikan ucapan terima kasih kepada :

1. Prof. Dr. dr. Adrian Umboh, Sp.A (K) selaku penguji I yang telah memberikan saran, masukkan, arahan serta perbaikan demi kesempurnaan skripsi ini

2. dr. Youla Assa M.Kes selaku penguji II yang telah memberikan saran, masukkan, arahan serta perbaikan demi kesempurnaan skripsi ini

\section{KEPUSTAKAAN}

1. Depkes. Pedoman Pelaksanaan Stimulasi Deteksi dan Intervensi Dini Tumbuh
Kembang Anak ditingkat Pelayanan Kesehatan Dasar, 2006.

2. Patmonodewo. Pendidikan Anak Pra Sekolah. Jakarta: Rineka Cipta, 2003.

3. Riyanto A. Aplikasi Metodologi Penelitian kesehatan.Yogyakarta: Nuha Medika, 2011

4. Sanjtaka. Aris. Statistik Untuk Penelitian Kesehatan. Yogyakarta: Nuha Medika, 2011.

5. Rahman. Karakteristik Perkembangan Anak Usia Dini. Yogyakarta: Lentera Pendidikan, 2009.

6. Permana. Pengaruh alat permainan edukatif terhadap perkembangan motorik anak pada taman penitipan anak [Tesis]. Medan; Universitas??; 2007

7. Nursalam. Dkk. Asuhan Keperawatan bayi dan Anak. Edisi Pertama. Jakarta: Salemba Medika, 2005

8. Soetjiningsih. Konsep Bermain Pada Anak dalam Tumbuh Kembang Anak. Jakarta: EGC,1995. 